\title{
The Collaborative Learning for Multicultural of Social Science with Lesson Study Pattern for Strengthening Student Character Education
}

\author{
Hairil Wadi* \\ Program Study of Sociology Education \\ Universitas Mataram \\ NTB, Indonesia \\ wadifkipunram@gmail.com
}

\author{
Ni Made Novi Suryanti \\ Program Study of Sociology Education \\ Universitas Mataram \\ NTB, Indonesia
}

\author{
Sukardi Sukardi \\ Program Study of Sociology Education \\ Universitas Mataram \\ NTB, Indonesia
}

\begin{abstract}
This study aims to implement collaborative learning of multicultural social science with lesson study patterns to strengthen student character education. The approach used is descriptive qualitative research. The data were collected by using observation, questionnaire, and documentation. The subjects of the study were social science teachers and students of class VIII and IX who were multicultural at junior high school 5 Narmada. The collected data were analysed by using the interactive model of Miles and Huberman which involves data reduction, data presentation, drawing conclusion or verification. The results showed that: 1) the stages of implementation (plan) - the planning stage in the form of problem identification, the preparation of the multicultural social science collaborative learning tool made by the social science teacher team; the implementation stage (do) - the implementation of multicultural social science with collaborative learning activities done by the model teacher; the reflection stage (see) - the social science teacher team provides an explanation of the strengths and weaknesses that will be encountered during the implementation of multicultural collaborative learning of social studies; 2) Strengthening the students' character education when implementing multicultural social science with collaborative learning such as religious, curiosity, responsibility, democratic, creative, friendly, communicative, peace-loving, and cooperation.
\end{abstract}

Keywords - collaborative, multicultural, lesson study, character

\section{INTRODUCTION}

Social science in junior high schools should ideally contribute to providing the wide space for students to think, communicate, and interact in the diversity of diverse social and cultural realities [1] because of social science as educational programs that nurture students to become good citizens in an atmosphere of peace. The indicators after students study social science are that they will have the competence to communicate, adapt, synergize well, and always think positively of others [2]. However, the reality is still at the theoretical level that is lacking in implementation. As a result, mutual respect is not internalized in students' personal mentality. Therefore, it requires a learning strategy that teaches the values of togetherness in terms of diversity, namely multiculturalism that can strengthen the education of students' character. Multiculturalism is a group of people who have different cultural backgrounds but can recognize diversity, differences, cultural diversity, ethnicity, and religion [3]. As that in one of the schools in West Lombok Regency, such as junior high school 5 Narmada.

The data show that students of junior high school 5 Narmada are included in the multicultural category in which the number of students are with different religion, ethnicity, and language. From the total number of students in class VII, 139 students, it was found that the Sasak Moslem students in class A were 17 students, class B were 17 students, class $C$ were 17 students, class D were 17 students, class E were 17 students. While the number of Hindu students were 54 students, the Balinese Hindu ethnic, in which 11 students in class A, 11 students in class B, 11 students in class C, 11 students in class D, 10 students in class E. Further, it was found that the number of students in class VIII was 104 students, in which the students with ethnic of Sasak Moslem in class A were 15 students, in class B were 16 students, in class $\mathrm{C}$ were 17 students, in class D were 15 students. While the number of students with Hindu were 41 students from the Balinese Hindu, in which 11 students were in class A, 10 students were in class B, 9 students were in class C, and 11 students were class D. While the number of students in class IX were 128 students, in which the students with ethnic Sasak Moslem were 12 students in class A, 11 students were class B, 11 students were in class C, 25 
students were in class D. While the number of Hindu students were 44 students from the Balinese Hindu in which 14 students were in class A, 15 students were in class B, 15 students were in class $\mathrm{C}$. The total number of students based on their religion and ethnicity were 371 students [4]. The multiculturalism of students in junior high school 5 Narmada is important for the development of strengthening character education through the implementation of collaborative learning.

Strengthening character education is applying the values of kindness by students when they are in formal level position and community such as the values of religiosity, nationalism, independence, mutual cooperation, and integrity [1]. Including in schools, especially in classrooms that are implemented operationally in learning and assessment through learning strategies with various learning methods in classes with different students in terms of race, culture, and social [5]. The results of the research from Clark \& Baker [6] explain that the application of collaborative learning in a diverse group gives a positive result. The innovation of learning activities can be designed by the teacher individually or in a collaborative team, called lesson study [7]. So this research implements social collaborative learning in multicultural classes in the lesson study pattern to strengthen the character education of students in junior high school 5 Narmada. The problem formulated in this study was "How is the implementation of collaborative learning of multicultural social science lesson study patterns for strengthening students' character education in junior high school 5 Narmada?", and the aim of this study was to implement the collaborative learning of multicultural social science lesson study patterns for strengthening students' character education in junior school 5 Narmada.

\section{RESEARCH METHOD}

This research used qualitative descriptive method approach conducted at junior high school 5 Narmada, West Lombok Regency. The subjects of this research were social science teachers and students of class VIII A and IX B. Data were collected by using observation sheet which included the implementation of collaborative learning for multicultural social science and strengthening the character education. The data obtained from research subjects were analyzed by using qualitative descriptive analysis stated in the Miles and Huberman model involving three processes, namely reducing data, presenting data, and drawing conclusions.

\section{RESULTS AND DISCUSSION}

The collaborative learning of multicultural social science was implemented by social science teachers in junior high school 5 Narmada for two rounds and the implementation of each round follows the pattern of lesson study. Round 1 was implemented in class IX $\mathrm{B}$, and round 2 in class VIII A. In the first round, the social science teacher team conducted: 1) The planning stage (plan), in the form of problem identification, problem solving, preparation of plans for implementing multicultural social science learning, preparation of student activity sheets and the observation sheets. The results of the problem identification indicated the lack of students' interest, enthusiasm and passion for social science learning, the students did not want to be in a group or to seat with friends whose religion and ethnicity are different. Further, it was found that there was lack of collaborative strategies used by the teacher, it was dominated by lecture methods, there was no media used, there was no initiative to classify students in terms of religion, ethnicity, and language. Problem solving determines the learning strategy of multicultural collaborative social science learning implementation of cooperative two stay two stray and talking sticks that are assisted by image media. Then preparing the learning implementation plan and student worksheet for collaborative learning of multicultural social science with cooperative model two stay two stray models and talking stick according to 2013 curriculum format, compiling an observation sheet for the implementation of learning and the students' responses to learning. 2) The implementation stage. Implementing the collaborative learning plan for multicultural social science with cooperative two stay two stray and talking stick models that have been prepared by the social science teacher team followed the steps below:

a) Preliminary activities: Teacher's activities: Greeting the students who are Muslim and Hindu "Good afternoon" (Hindu teacher), inviting students to pray according to students' religion and beliefs, motivating students "Keep our diversity to be always safe and peaceful in the differences that are blessed by God Almighty", inspiring students with multicultural yells "Multicultural Greetings", asking students about last week's material, dividing students into 5 multicultural groups with stages of grouping based on religion (Hinduism, Islam), then asking students who are Hindu and Muslim to split up according to the division of multicultural groups (religion, ethnicity, culture, language, region), after that asking a representative from each group to take the topics (economic, social, cultural, education) showing images of space interaction between countries. Students' activities: answering the teacher's greetings. "Good afternoon", praying according to their religion (Islam and Hinduism), Chanting yells of multicultural "We are diverse in ethnicity, religion, culture, language, we are proud of Indonesia yes, yes, yes, answering the teacher's question "The effect of interaction between spaces on economic, 
social and cultural life", taking topics in turns based on large groups (religion), spliting up according to multicultural groups (religions, ethnicities, cultures, languages, regions), observing various images related to the influence of spatial interactions on economic, social, cultural and educational life. b) Main activities: Teacher's activities: distributing to students the worksheets of activities, explaining to students operationally the material being studied, asking the students to study the topics that have been obtained in each multicultural group, answering the card questions, asking each group member to answer the question card such as "Explain the reasons for the interaction between spaces on economic life", asking the students to display their work, ask each member of the multicultural group to start visiting (2 wait for guests, and 3 visits), each group is given two colored paper, asking each multicultural group to write questions on the paper to be presented to the other groups, paper that has been written questions are rolled like sticks and this activity is accompanied by a song from the Sasak tribe (Amak tegining inak tegamang: Lombok), Balinese Hindu traditional song (Meow: Bali). Students' activities: each group complete the multicultural group activities, write down the results of work on colored paper, sticking paper creations that contain answers to large-sized cardboard paper accompanied by slogans like "I'm my culture, Indonesian culture", each group display their multicultural work in the walls of the classroom, each member of the group visits ( the three who visited, two the visits, each group member who visited brought a note to get information from each group member, each relearns the results of the visit so that they can answer questions with sticks, each multicultural group performed a stick activity accompanied by the Sasak song "Ama tegining inak tegamang and a Balinese song" Meow. c) Closing Activities. Teachers' activities: Giving multicultural group members the opportunity to ask questions that are not yet understood, concluding the material that has been discussed, inviting the students to chant the Yells "Multicultural Greetings ", giving gifts to multicultural groups whose answer is correct, whose work is creative, and whose yell is interesting, giving learning outcomes tests. Students' activities: answering the teacher yell "We are diverse in ethnicity, religion, culture, language, We are proud of Indonesia Yes, yes, yes", answering the material test questions that have been discussed.

Reflection stage. The social science teacher team reflected on the implementation of the multicultural social sciences collaborative learning that had been conducted by the model teacher. The contents of reflection are advantages and disadvantages. Advantages: structured lesson plan, student activities sheets, use of sources (internet, teacher-student books), utilization of image media and LCD, implementing the steps of collaborative learning multicultural models cooperative learning type with two stay two stray collaboration talking stick, conducting material evaluation activities that have been discussed. Disadvantages: the model teacher did not explain the steps of collaborative activities to students, the model teacher forgot to apply some of the steps of the learning activities, The model teacher did not manage the time of collaborative group activities appropriately.

Meanwhile, the student responses to collaborative learning with multicultural that have been planned and implemented by the social science teacher team (lesson study) indicate that there was no objection and disruption in collaboration with different religions and ethnicity because all of them are Indonesian people who respect differences, the students did not reduce the spirit of learning and working together and helping each other, they feel safe and comfortable being able to share with others, completing the assignments, they can complement each other, they discuss together and are activate, have fun, there is dialogue between groups of work through visits, they can exchange ideas and discuss issues together.

Next round 2, namely 1) The planning stage, in the form of problem identification, problem solving, determination of class implementation, preparation of lesson plans for social science class VIII, preparation of student activities sheets and observation sheet on the learning process. The results of the identification of problems gotten from students are: lack of motivation and enthusiasm for social science, lack of desire to sit in pairs and cooperate with friends of different religions, ethnicities, and languages. Whereas from teachers: lack of application of learning methods that motivate students to collaborate with friends of different religions, ethnicities, languages, lack use of media and student worksheets.

Then the results of Problem Solving. The social science teacher team determine learning method for collaborative multicultural of social science model with cooperative group investigation and snowball throwing assisted by images media, power point and teaching aid such as laptop and LCD. Prepare learning implementation plans and student worksheets collaborative learning social science application of cooperative group investigation and snowball throwing according to the 2013 curriculum format in class VIII A. Then the results of the observation sheet were the implementation of learning and student responses to learning. 2) The implementation stage. The implementation of the lesson plan of collaborative learning social science multicultural application of cooperative group investigation and snowball throwing assisted by 
images media, power point and help tools with laptop and LCD. The activities of teachers and students are: Preliminary activities: Teacher's activities: Greetings the students with Assalamualaikum (Muslim teacher) to those who are Muslim and with "Good afternoon" to those who are Hindu, inviting students to pray according to students' religion and beliefs, inviting students to sing the song" Dari Sabang sampai Marauke," invitings students to chant Multicultural Yells. "Multicultural Pat", giving questions related to the material learned last week, conveying information on topics and learning objectives, grouping students into large groups based on religion (Islam-Hindu) with multicultural techniques (religion, ethnicity, culture, language). Students' activities: answering the teacher's greetings "Waalaikum salam warahmatullah wabarkatuh" (Islam), "Good Afternoon" (Hindu), praying according to students religion, simultaneously singing the song "Dari Sabang sampai Marauke," answering the multicultural Yells of the teacher "Bu-da-Ya Culture, A -ga-ma religion by clapping "We are students of SMP 5 Narmada united in peace; Yes yes yes ", listening to the teacher convey the topic and learning objectives or competencies to be achieved. Main Activities: Teacher's activities: asking multicultural group to take the envelope division of the topic, asking each multicultural group to complete the topics that have been obtained and prepared the yells that will be done before doing the presentation, asking each multicultural group to investigate and report the results of its work, asking each multicultural group to investigate and report the results of their work. After that the questions are written on paper made like a ball according to the number of member of cultural group throwing ball papers at ethnic groups and ethnic groups at cultural groups, religious groups throwing at language groups, language groups throwing at religious groups. Students' activities: dividing into groups based on religion, ethnicity, language and culture, each multicultural group takes the topics in the envelope, gets the topics that will be investigated, investigates the topics that have been obtained, each investigation group analyzes and summarizes from student books, each multicultural group presents the results of the investigation that interspersed with diversity yells, each member of a multicultural group does the reading activity for ten minutes from the presentation of the investigation group, each member of the multicultural group makes a presentation and notes for what is listened, each multicultural group makes a question that has been listened to from the presentation of other groups, among multicultural groups throwing paper balls. Closing Activities: Teacher's activities: asking students to conclude the material that has been discussed accompanied by the yells of diversity: "Teacher: Diversity" giving the competency test. Students' activities: concluding, answering the teacher's yells: "We are different religions, different ethnic groups, different languages, but we are still one. Indonesia, Indonesia, I will still defend you, ". Students answer the test items in the description of the material that has been discussed.

3) Reflection stage. In the reflection stage, the social sciences teacher team reflected on the collaborative learning of multicultural social sciences implemented by the model teacher in class VIII A, especially those dealing with the advantages and disadvantages and suggestions. Advantages: implementing the steps learning activities of collaborative learning social science model group investigation and multicultural snowball throwing, conducting material evaluation activities that have been discussed. Disadvantages: the limited time in implementing the strategy so that there were steps of activities missed by the model teacher. Suggestions: it is important to implement student collaboration in social science learning activities in all basic competencies. Meanwhile, the responses to the implementation of collaborative learning for multicultural social science obtain from ten students as representatives indicate that they did not feel bored in grouping collaboratively based on differences in religion and ethnicity, the students do not feel disturbed, collaborative learning teaches unity and integrity, it is fun like the colors of the rainbow which is not monotonous, it is attractive, safe, comfortable, and provides important experiences of differences by interspersed with yells before the presentation and it supports each other in completing the task.

The implementation of collaborative learning in multicultural social science round 1 in class IX B and round 2 in class VIII A with multicultural classes of religion, ethnicity, and language (Islam-Sasak, Hindu-Balinese) showed a number of issues strengthening student character education, such as: 1) religious: students pray according to their respective religions; 2) curiosity: students in multicultural groups of religion, ethnicity, and language study the sub topics (student books, teacher books, worksheets) and ask questions between collaborative groups; 3) tolerance: praying according to the way and belief, Islam students pray together "Raditubillahi rabba wabil islamidina wa bi muhammadin sallahu alahi wassalam rasula" While, Hindu students pray in the way of Hindu religion, in silence without speaking. The greeting among the Muslim or Islam students is "Assalamualaikum Warahmatullah wabarkatuh", and the greeting among Hindu students is "Om suasti astu", while the greeting between Islam and Hindu students or vice-verse is "Good morning/afternoon"; 4) respect: students want to listen to people who are greeting according to their religions; 5) responsibilities: completing group tasks by collaborating in multicultural groups; 6) democratic: collaborative group work among different religions, ethnicities, and languages; 7) creative: decorating collaborative work on paper, displaying work and writing on color variation paper, singing multicultural chants; 8) friendly: conducting presentations on the work of multicultural religious and ethnic groups; 9) cooperation: working on assignments together in multicultural collaboration groups; 10) peace-loving: helping each other to complete the multicultural 
collaboration activities of religion, ethnicity, and language.

From the explanation of the data above, it can be discussed that the implementation of collaborative learning of multicultural social science lesson study patterns by a team of social science teachers who teach in class VIII and class IX in junior high school 5 Narmada are conducted through stages, including 1) the planning stage (plan) in the form of identifying learning problems in multicultural classes such as classes VIII A and IX B, determining collaborative learning (two stay two stays, talking sticks, group investigations, snowball throwing), designing the lesson plans and worksheets, determining the media, and the evaluation, the observation sheet for learning implementation; 2) the implementation stage, in which the model teacher conducted a multicultural social science collaborative learning implementation plan; 3) reflection stage (see), in which the social science teacher teams make reflection on the observations that have been made (advantages and disadvantages) including students' responses to learning activities. Researcher's statement that the implementation of collaborative learning for multicultural in social science subjects has provided improvement in teaching, increased experience, and added knowledge to create collaboration between teachers of similar subjects. This is in line with research from [8] the China Lesson study (CLS) which encourage a deliberate practice for developing instructional expertise improvement science for instruction and school improvement system wide.

The implementation of collaborative learning in multi-cultural social science in class VII A and IX B can develop the strengthening of student character education. It is evident from the activities of students when collaborating because of differences in religion, ethnicity, and language. Starting from the beginning, the students have multicultural yells, conduct activities among multicultural collaboration groups (religion-ethnicity, language), identify topics among multicultural groups, observe pictures among multicultural groups, communicate among multicultural groups. The collaborative learning as a learning strategy has been able to unite students who have differences in diversity. Linda Campbell, et al. [9] explain that collaborative learning can create positive actions towards learning that has been done and help to create of a sense of togetherness among students. Collaborative learning implementing cooperative learning in diverse classes creates tolerance and acceptance of diversity [10]. Collaborative learning in multicultural that conducted by the social science teacher team creates positive character education for students including religious, tolerance, friendship, responsibility, creative, cooperation, respect, democratic. As the students in junior high school 5 Narmada have a diverse school culture or multicultural, the teacher and the principal need to pay attention to learning that implement collaboration through cooperative activities or collaboration between different students so as to reduce the problem of discriminating student status in accordance with their religions, cultures, ethnicities and languages.

\section{CONCLUSION}

The implementation of collaborative learning of multicultural for social studies with lesson study patterns can strengthen the student character education such as religious character, curiosity: tolerance, respect, responsibility, democratic, creative, friendly, cooperation and peace-loving.

\section{REFERENCES}

[1] M. of Education, "Standard content of primary and secondary education," Jakarta, 2006

[2] Saidihardjo, Pengembangan materi IPS Terpadu (Diktat). Yogyakarta: Yogyakarta State University Postgraduate Program, 2008

[3] N. Naim and A. Sauqi, Pendidikan Multikultural: Konsep dan Aplikasi. Yogyakarta: Ar-Ruzz Media, 2008.

[4] S. 5 Narmada, "Data of students at junior high school 5 Narmada in academic year 2019/2020," Lombok Barat, 2019.

[5] J. Banks, Teaching strategies for etnic studies. Newton: Allyyn and Bacon, 1984.

[6] J. Clark and T. Baker, Collaborative learning in diverse groups: a New Zealand experience. 2007.

[7] D. Hendayana, Lesson Study Suatu Strategi Untuk Meningkatakan Keprofesionalan Pendidik (Pengalaman IMSTEP-JICA). Bandung: UPI Press, 2007.

[8] R. Huang, Y. Fang, and X. Chen, "Chinese lesson study: a deliberate practice, a research methodology, and an improvement science," Int. J. Lesson Learn. Stud., 2017.

[9] L. Cambel, Metode praktis pembelajaran berbasis Multiple intelegences. Intuisi Press, 2006.

[10] Arends, Learning to teach. Jakarta: Pustaka Pelajar, 2008. 